\title{
Impacts of green tides on estuarine fish assemblages
}

\author{
Paumier A. ${ }^{1,2,{ }^{*}}$, Tatlian T. ${ }^{1}$, Reveillac E. ${ }^{1}$, Le Luherne Emilie ${ }^{1,3}$, Ballu S. ${ }^{4}$, Lepage M. ${ }^{2}$, \\ Le Pape Olivier ${ }^{1}$
}

${ }^{1}$ Agrocampus Ouest, INRA, Ecol \& Ecosyst Hlth, ESE, F-35042 Rennes, France.

2 Irstea, EABX, Aquat Ecosyst \& Global Changes, F-33612 Cestas, France.

${ }^{3}$ IFREMER, Dept Fisheries Sci \& Technol, F-29280 Plouzane, France.

${ }^{4}$ CEVA, Presquile Pen Lan BP3, F-2610 Pleubian, France.

* Corresponding author : A. Paumier, email address : alexis.paumier@irstea.fr

\begin{abstract}
:
All around the world, an increasing proportion of estuarine systems are facing massive proliferations of green macroalgae, called green tides, in response to nutrient enrichment. The consequences of this perturbation for ichthyofauna that use estuarine systems as essential fish habitats remain understudied. To estimate these consequences, we combined outputs of both macroalgae proliferation and fish community surveys conducted for the European Water Framework Directive in thirteen estuaries in northwestern France, a region where green tides are of great concern. The approach revealed the influence of green tides on estuarine fish communities. The response of each community to the green tides differed according to their functional guild composition. Benthic and marine juvenile guilds were negatively impacted, while demersal and pelagic fish guilds appeared to be more resilient. Green tides, which significantly affect the suitability of fish habitat, change the composition of the fish community and may hinder the future recruitment of marine fish species that rely on estuaries during the juvenile stage.
\end{abstract}

Keywords : Fish community, Estuarine ecology, Green tides, Macroalgae, Nursery 


\section{Introduction}

Estuarine systems host a variety of habitats that are associated with high food availability and represent essential habitats for ichthyofauna (Blaber and Blaber, 1980; Elliott and Dewailly, 1995; Peterson, 2003; Nicolas et al., 2010). These ecosystems provide major ecological services to fish communities, such as nursery grounds for juveniles, foraging areas for adult marine fish, permanent habitats for many resident species, and migration corridors for amphidromous fish (Seitz et al., 2014). Habitat quality and associated ecological services play a key role in the sustainability and renewal of a large number of estuarine-dependent fish that rely on estuaries during at least one stage of their life cycle.

However, these essential habitats are facing high and increasing anthropogenic disturbances (Beck and Airoldi, 2007; Brown et al., in press). The excessive input of organic matter and inorganic nutrients derived from anthropogenic watershed activities represents one of these disturbances (Diaz and Rosenberg, 2008; Liu et al., 2013; Lyons et al., 2014). The increase in nitrogen inputs beyond the level of an estuary's self-regulatory capacity (i.e., eutrophication) often leads to the increased development of a few taxa of fast-growing green macroalgae (Nixon, 1995; Valiela et al., 1997; Anderson et al., 2015), which causes green tides (GTs). In recent decades, the abundance and duration of GT events have increased worldwide (Hodgkin and Birch, 1986; Pihl et al., 1995; Fletcher, 1996; Lehvo and Bäck, 2001, Ye et al., 2011; Smetacek and Zingone, 2013). While the drivers and processes of these proliferations are known, their effects on ecosystems have been sparsely described (Lyons et al., 2014). During a GT, major changes occur in the habitat conditions (Fletcher, 1996). Biogeochemical cycles (Sfriso and Pavoni, 1994) and habitat structure modifications (Isaksson et al., 1994; Sundbäck et al., 1996) have been reported to impact invertebrate communities (Quillien et al., 2015) and 
trophic webs (Raffaelli et al., 1998). However, only a few studies have considered the fish community, especially in estuarine systems (Raffaelli et al., 1998; Lyons et al., 2014).

During recent decades, the intensity of GTs and the number of impacted sites have increased in northwestern France, with high levels of proliferation observed from mid spring to the end of summer (Ménesguen and Piriou, 1995). Locally, a small-scale analysis of shallow intertidal beaches and estuarine mudflats revealed differences in the fish communities between control and impacted sites during green algae proliferation. Negative impacts for benthic and marine juvenile fish species begin at a low proliferation rates, and green tides significantly decrease fish species diversity and overall fish density until the complete disappearance of fish at a high level of GT (Le Luherne et al., 2016). Proliferations of green macroalgae and fish communities are both monitored in this region to assess the ecological quality of estuarine systems and to achieve a status that is compliant with the goals of the European Water Framework Directive (WFD). Complementing the previous local small-scale approach (Le Luherne et al., 2016), this study provides a quantitative evaluation of the effects of contrasting levels of GT proliferation on fish communities in estuaries over a much larger geographic area. The effects of GTs on fish communities were examined through the analysis of fish density and species richness collected from thirteen estuaries to explore the following questions:

- Is there a significant difference between the fish communities in affected and non-affected

estuaries?

- At what scale can we detect GT impacts on estuarine fish communities?

- Do functional groups of fish respond differently to GTs? 


\section{Materials and methods}

71

72

73

\subsection{General approach}

To study the effects of green tides on estuarine fish, a generalized linear model (GLM) approach was applied (2.5.). We used several survey-based (2.2.) descriptors of the fish community (2.3). The "natural" environmental variability of fish in estuaries was integrated by using four major environmental variables that control fish assemblage (i.e., ecoregion, season, depth, and salinity; Courrat et al., 2009; 2.3.). Then, we tested separately the GT effect using four descriptors, from a large scale to a local scale (2.4.).

\subsection{Study area and fish sampling}

We investigated the effect of GT in thirteen estuaries located in northwestern France (Fig. 1).

The selection of these study sites allowed the coupling of fish survey and green tide indicator data. Furthermore, the pressure represented by GTs differed among these estuaries (e.g., from non-affected to moderately affected. These estuaries qualities were evaluated by ELFI, which is an indicator of estuarine quality based on the fish metrics (Table 1).

From 2008 to 2014, fish were sampled in thirteen estuaries as part of a monitoring program that evaluates the ecological status of transitional waters in relation to the WFD (Delpech et al., 2010). Standardized fish surveys were conducted in spring (between April and June) and autumn (between September and November) for each site and sampling year (Delpech et al., 2010). Each survey used a beam trawl with an opening of $1.5 \mathrm{~m}$ wide and $0.5 \mathrm{~m}$ high and with a 8-mm stretched mesh in the cod-end (Delpech et al., 2010). The beam trawl was hauled in a counter-current direction for 15 min at a standard speed of 1.5-3 knots (Delpech et al., 2010). An average bottom surface of $1100 \mathrm{~m}^{2}$ was swept during each haul. Salinity and depth were recorded for each beam trawl haul, the depth ranged between 0.75 and $23 \mathrm{~m}$, and the salinity 
ranged between 2.5 and 35.1. From 2008 to 2014, 1348 beam trawl hauls have been conducted, and 85 fish species and 79,125 individuals have been sampled.

\subsection{Fish community metrics and environmental variables}

Fish density and species richness were selected as indicators of the fish community status because they are assumed to decrease with an increase in habitat disturbances (Gibson, 1994; Delpech et al., 2010). Species richness was estimated based on the number of species captured in each trawl haul, and the total density was defined as the number of individuals captured per hectare. In addition, to evaluate the impact of GTs on the use of fish habitat, each species was classified into functional guilds, including: 3 vertical distribution guilds (i.e., pelagic, demersal and benthic) and 2 ecological guilds (i.e., marine juvenile and resident) (Franco et al., 2008; Potter et al., 2015). Vertical distribution guilds describe the spatial distribution of fish in the water column and illustrate the dependence of the organism on the substratum (Table 2). Ecological guilds describe the use of estuaries during the species' life cycle (Table 2). Other ecological fish guilds, such as amphidromous or marine adventive species (Elliott and Quintino, 2007), were not well sampled in the beam trawl surveys; thus, our approach did not account for these guilds. The fish densities for each of these five guilds were calculated for each trawl haul.

Because estuaries are exposed to strong environmental gradients, it was necessary to consider the natural source of environmental variability (Elliott and Quintino, 2007; Courrat et al., 2009; Nicolas et al., 2010) before providing a reliable assessment of the green tide impacts on estuarine fish communities. Four main environmental variables were considered: the sampling season of the survey, the ecoregion where the estuary is located, the salinity and the depth during the trawl haul. Preliminary tests have shown that these four sources of environmental variability were not correlated. 
117 - Fish communities change dramatically between spring and autumn (Elliott and Quintino,

118 2007). The most marked shift was observed for marine juveniles, whose density decreased

119 drastically from spring to autumn, revealing a high mortality rate after settlement (Courrat et

120 al., 2009; Le Pape and Bonhommeau, 2015). These density variations and the seasonality of

121 GT proliferations led us to separate spring and autumn analyses.

122 - A biogeographic classification based on the Marine Ecoregions of the World (Spalding et

123 al., 2007) was used to separate the thirteen estuaries into two ecoregions: "North Brittany"

124 and "South Brittany" (Fig. 1).

125 - Salinity and depth, which are among the main drivers structuring fish communities in 126 estuaries, were (Courrat et al., 2009) also considered.

\section{$127 \quad 2.4$ Green tide monitoring in WFD and GT index computation}

128 To quantify the intensity of the GTs, we used four indicators provided by the Center for Study

129 and Promotion of Algae (CEVA, France) and the WFD (Table 3). Three of these indicators

130 (GT1, GT2 and GT3) were based on quantitative maps of GT, and the last indicators (GT4)

131 was based on a WFD indicators (Table 3). The quantitative maps were obtained by

132 combination of orthophotographies and field monitoring. Orthophotographies were obtained

133 from an aircraft during low tide, and field monitoring was performed to determine the 134 associated density of macroalgae. The quantitative maps represented the macroalgal 135 proliferation as a percentage of algal cover. The first three indicators of GTs were derived 136 from these maps at different spatio-temporal scales (Table 3):

137 - At a large scale (i.e., the estuary scale), the ecological quality ratios (EQRs) were used

138 (GT1). The EQR index is a validated indicator of estuarine quality in terms of macroalgal

139 proliferation that is applied in the WFD (Wilkes et al., 2014). The EQR index is composed of 140 four scores: poor, moderate, good and high. Inside each of the thirteen estuaries, a low 
141 variability of the EQR was observed over the period of 2008-2014 (Supp. Fig. 1.1). Among

142 the thirteen estuaries, some were almost clear of green macroalgae (high), while others were

143 impacted by GTs (moderate, Table 1). No poor EQR were recorded within the studied

144 estuarine.

145 - At a local scale (i.e., the trawl haul scale), we used two indicators based on the same data

146 (Table 3): (i) the macroalgal mat surface ratio within the trawl hauls (GT2), and (ii) the

147 macroalgal mat surface ratio near the trawl hauls (GT3). The macroalgal mat surface ratio

148 within the trawl hauls (GT2) was computed using QGis software by combining the

149 quantitative maps of macroalgal proliferation with the trawling location from 2008 to 2014

150 (which was the same period as the fish trawl surveys). Preliminary analysis and expert

151 knowledge validated the inter-annual steadiness of this distribution. The macroalgal mat

152 surface ratio near the trawl samples (GT3) was also computed by combining the quantitative

153 maps of macroalgal proliferation with the trawl haul location. To achieve this, a surface buffer

154 was calculated around each beam trawl haul (Supp. Fig. 2.1). Several surface buffers were

155 calculated to compute the index of the macroalgal surface ratio near the trawl hauls with

156 different buffer distances (i.e., from 100 to $1000 \mathrm{~m}$ ). Inside each buffer, the proportion of sea

157 surface (excluding land cover) covered by green macroalgae was calculated up to a certain 158 threshold (i.e., $>25 \%,>50 \%$ and $>75 \%$ ) (Supp. Fig. 2.1). The influence of the buffer distances

159 and thresholds was assessed in preliminary analysis before the GT3 was integrated as

160 explaining covariates in the models of fish metrics. We screened the correlation levels

161 between the GT index in the vicinity of trawl hauls according to the different buffer distances

162 that were defined around the beam trawl hauls (ranging from 100 to $1000 \mathrm{~m}$ ) and the different

163 algal cover thresholds ( $>25 \% ;>50 \%$ and $>75 \%)$. 
164 In addition, at a local scale, we tested a fourth GT descriptor on a restricted dataset. The Ulva

165 spp. density per beam trawl (GT4) was estimated from an additional protocol added to the

166 WFD trawl surveys in 2013 and 2014 (Table 3). These data were available for 227 beam trawl

167 hauls and were collected using a WFD standardized protocol (Scanlan et al., 2007)

168 The influence of each of these four indicators on fish metrics was tested separately to

169 determine the most appropriate scale for assessing the effect of GTs on estuarine fish.

\section{$170 \quad 2.5 \quad$ Modelling the effect of GTs on the fish community}

171 The multi-scalar approach used for the GT indicators allowed us to explore the appropriate

172 scale for detecting the impacts of GTs on fish communities. Because there is no optimal scale

173 to describe an ecological phenomenon (Levin, 1992; Wheatley and Johnson, 2009), we chose

174 to compare the response of the fish community to these four GT indexes in separate analyses.

175 The modelling approach integrated the response of fish to the natural variability and the four

176 GT indexes used in four separate models (Eq. 1):

177

$$
\text { Fish metrics } \sim \text { environmental variables }+ \text { GT }^{*} \quad \text { (Eq. 1) }
$$

178 where the environmental variables represent the four natural drivers (i.e. ecoregion + salinity

$179+$ depth), and "GT*" corresponds to one of the four GT metrics (Table 3).

\subsubsection{Species richness}

181 The species richness was modelled using GLM with a Poisson distribution (Eq. 2). This

182 distribution is most commonly used for analysing count data in trawl surveys (Courrat et al., 183 2009).

184 Species richness $\sim($ environmental variables $)+\left(\mathrm{GT}^{*}\right)+\varepsilon \quad($ link function $=\log ) \quad($ Eq. 2$)$

185 where the environmental variables represent the four natural drivers, and "GT*" corresponds 186 to one of the four GT metrics (Table 3). 
188 The fish survey data were characterized by a large proportion of zeros (Supp. Fig. 1.2.a).

189 According to this zero-inflated distribution, we used a delta distribution (Aitchison and

190 Brown, 1957). This approach is appropriate for the analysis of fish survey data (Stefansson,

191 1996; Le Pape et al., 2003). The delta model (Aitchison, 1955; Pennington, 1983) combines

192 two distinct GLMs: one sub-model for fish presence and absence (Eq. 3), and one sub-model

193 for positive density (Eq. 4).

194 - Binomial sub-models for fish presence

195 $\mathrm{Y}_{(1 / 0)} \sim($ environmental variables $)+\left(\mathrm{GT}^{*}\right)+\varepsilon \quad$ (link function $=$ logistic $) \quad$ (Eq. 3)

196 where $Y_{(1 / 0)}$ represents the presence or absence of fish (i.e., 1 or 0 ). The area under the curve

197 (ROC) was used as a criterion to validate the goodness-of-fit of each sub-model (Manel et al., 198 2002; Vasconcelos et al., 2013).

- Sub-models for positive fish density

$$
\log \left(\mathrm{Y}_{(>0)}\right) \sim(\text { environmental variables })+\left(\mathrm{GT}^{*}\right)+\varepsilon(\text { link function }=\text { identity })(\text { Eq. } 4)
$$

201 where $\mathrm{Y}_{(>0)}$ is the density of fish when at least one fish was caught. The log-transformed 202 positive densities satisfy the conditions of a linear distribution and the homogeneity of 203 variance for these sub-models (Supp. Fig. 3.1.). The value of the actual data vs. the predicted 204 relationship was used as a criterion to validate the goodness-of-fit of these sub-models (Manel 205 et al., 2002; Vasconcelos et al., 2013).

206 - Coupling

207 The two sub-models (Eqs. 3 and 4) were coupled (Eq. 5) to estimate fish density (Stefansson, 208 1996). A correction was applied to the positive sub-models to obtain unbiased estimations 209 from log-transformed data (Laurent, 1963). 


$$
\hat{Y}=Y_{(1 / 0)} * e^{\ln \left(Y_{(>0)}\right)} * e^{\frac{\alpha^{2}\left(\ln \left(Y_{(>0)}\right)\right.}{2}}
$$

211 where $\hat{Y}$ is the fish density estimated by the delta model; $Y_{(1 / 0)}$ is the probability of the 212 presence of fish provided by the binomial model; $\mathrm{Y}_{(>0)}$ is the logarithmic density of fish 213 provided by the log-normal model; and $\alpha^{2}\left(\ln \left(\mathrm{Y}_{(>0)}\right)\right.$ is the standard error associated with the 214 log-normal model.

215 To quantify the uncertainty that accounts for the combination of the two sub-models' errors, 216 we used a random sampling approach. We predicted the presence of fish on 5,000 subsamples 217 that were randomly generated with the binomial model, and we log-transformed the densities 218 of 5,000 subsamples that were generated with the GLM model using positive density values. 219 Then, these predictions were coupled, and we computed the 10\%, 50\% and 90\% quantiles of 220 the 5,000 predictions (Courrat et al., 2009).

\subsubsection{Preliminary analysis and modelling options}

There was a single exception to the use of the delta model, and it concerned the pelagic fish guild. The proportion of non-null observations of pelagic fish was too low to allow for fitting

224 a positive sub-model. As a result, a single binomial model (Eq. 3) was developed for this 225 guild (Table 4).

226 The GLM approach requires linearity in the relations between the response variable and the covariates. This assumption was preliminarily tested before the integration of the 2 environmental variables (e.g., depth and salinity, and ecoregion was a class factor) as linear factors in the GLM. For depths down to $16 \mathrm{~m}$, we observed atypical observations and non-linear effects on fish metrics. Thus, to account for the linear effect of depth, we removed trawl samples 231 that were deeper than $16 \mathrm{~m}$. By doing so, we narrowed the data set by less than $1 \%$ of the survey 
232 data. In a few other cases where we found non-linear patterns, we integrated the

233 environmental variable as a class factor in the GLMs (see pelagic fish in Table 4).

234 The models were run using $\mathrm{R}$ software ( $\mathrm{R}$ Core Team 2016). For both sub-models, the

235 selected level of statistical significance of the four environmental variables and the GT 236 indexes of the GLM was 5\% (i.e., only the environmental variables that were significant at the $2375 \%$ level were retained, and the same was applied to GT*). Both the explained percentage of 238 deviance and the Akaike information criterion (AIC) were used to assess the effects of the 239 environmental variables and the GTs on the fish metrics.

\section{Results}

\section{$241 \quad 3.1 \quad$ Fish community and its environmental variables}

242 The majority of fish caught belonged to the demersal (71.5\%) and benthic (26.6\%) guilds, 243 while a minority of fish were pelagic (1.9\%). For the ecological guilds, the residents were the 244 most frequently caught species (70\%), followed by the marine juveniles (13\%). Other 245 ecological guilds were poorly represented and were, thus, not included. Globally, the 246 statistical significance of depth and ecoregion were high in the models, and the salinity 247 appeared to be a structuring factor for the density of the benthic and marine juvenile guilds in 248 spring (Table 4). Selected models had satisfying goodness-of-fit values (Supp. Table 3.1; 249 Supp. Fig. 3.1).

\section{$250 \quad 3.2 \quad$ GT index computation}

251 The study revealed that few beam trawls were conducted within the algal mat: 54 trawl hauls 252 occurred in spring and 71 hauls occurred in autumn (i.e., 9\% of the fish community data). 253 Furthermore, the macroalgal mat surface ratio (GT2) was very low at these 125 beam trawl 254 hauls. Accordingly, the green macroalgae density accumulated per beam trawl haul, which 
255 was available in 2013 and 2014 (GT4), was very low (mean biomass $=0.0035 \mathrm{~kg} / \mathrm{m}^{2}$, Supp.

256 Fig. 1.2.b).

257 The macroalgal mat surface ratio near the beam trawl haul (GT3) differed among the

258 threshold and buffer combinations. For identical buffer distances, the different algal cover 259 thresholds were correlated (more than 80\%; Supp. Fig. 2.2.). In the radius range of 300-800 $260 \mathrm{~m}$, the levels of correlation were also high between the GT indexes for the different buffer 261 sizes and the algal cover thresholds (Supp. Fig. 2.2.). We selected a single combination of 262 buffer distance and algal cover to compute the macroalgal mat surface ratio near the beam 263 trawl hauls (GT3): the 25\% threshold of algal cover within the $500 \mathrm{~m}$ buffer.

\section{$264 \quad 3.3 \quad$ Large-scale effect of GTs}

265 Accounting for the statistical significance of the environmental variables (Table 4), the 266 significant effects of the EQR (GT1) were detected for 13 of the 14 models in spring and for 26711 of the 14 models in autumn (Table 4). However, a single fish metric - the density of 268 benthic fish in spring - had a monotonous relationship with GT1 (i.e., a continually 269 decreasing density associated with a decreasing gradient of the EQR). Moreover, the deviance 270 explained by GT1 for the density of benthic fish was the highest (32\% for the presence271 absence model and $2 \%$ for the positive density model). Furthermore, the confidence bands 272 around the prediction associated with the average and high EQR scores did not overlap, and 273 there was a distinguishable difference in density (Fig. 2). GTs negatively impacted the benthic 274 guild in spring. The deviance explained for the other fish metrics was less than $10 \%$. 275 According to this low signal at the estuarine scale, there was no significant correlation 276 between GT1 and ELFI. 


\subsection{Local-scale effect of GT}

278 Accounting for the statistical significance of the environmental variables, the two indexes of 279 proliferation at beam trawl locations (GT2 and GT4) were not statistically significant for 280 either the spring or autumn surveys.

281 Conversely, statistically significant effects (Table 4) were observed for the algal cover near 282 the beam trawl haul (GT3). In spring, the probability of the presence of the resident guild 283 responded to GTs positively. In autumn, statistical significance was detected for 6 of the 12 284 models. Positive effects of the GTs were observed on total fish density, demersal fish density, 285 and resident fish density. In contrast, GTs had a negative effect on the benthic and marine 286 juvenile fish densities. The density of marine juveniles was halved when $20 \%$ of the surface at 287 an area less than $500 \mathrm{~m}$ from a beam trawl haul had a green macroalgae cover greater than $288 \quad 25 \%$ (Fig. 3).

\section{Discussion}

290 This study provided evidence on the effects of GTs on estuarine fish communities, and it

291 focused on thirteen estuarine systems with contrasting levels of GTs. It appeared that GTs had 292 both negative and positive effects on the fish communities. Benthic fish were especially 293 sensitive and negatively impacted, and marine juveniles appeared to be dramatically more 294 sensitive than were resident fish. This confirmed previous findings from coastal areas (Howell 295 et al., 1999; Jokinen et al., 2015; Le Luherne et al., 2016), and enabled us to extend these 296 conclusions to estuaries.

\subsection{Can we consider correlations to GT indexes as causal links to GTs?}

298 Fish that inhabit estuaries have adapted to strong environmental gradients (e.g., "estuarine 299 quality paradox" theory; Elliott and Quintino, 2007). Thus, it was critical to consider the 
environmental constraints before providing a reliable assessment of the impacts of GTs on the

301 estuarine fish communities (Nicolas et al., 2010). Accounting for these "natural" factors that structure fish communities at different scales (time: seasonal patterns; space: ecoregion at a mesoscale, depth and salinity at a local scale) allowed us to account for a part of the "natural"

304 variability and autocorrelations in the fish survey data, which enabled a reliable assessment of 305 the effects of GTs.

306 In addition, the potential effects of the other anthropogenic pressures potentially combined 307 with the effects of GTs were not considered. The lack of an exhaustive assessment of the 308 ecological status of these thirteen estuaries in the WFD, e.g., with regard to the concentration 309 of xenobiotics, prevents the present approach from accounting for them. These potential 310 confounding factors smooth the strength of the conclusions based on analysis at the estuarine 311 scale. However, the use of local-scale GT indexes, especially GT3, allows for a thin-scale 312 analysis of the link between GTs and fish metrics, with a dramatically less probable influence 313 of potential confounding factors.

\section{$314 \quad 4.2 \quad$ Large-scale impacts of GT}

315 At the large scale, a single negative effect of GTs was revealed on the benthic guild. It was 316 previously demonstrated that this guild was the most sensitive to green macroalgae 317 proliferation (Bowen and Valiela, 2001; Bricker et al., 2008; Le Luherne et al., 2016, 2017). 318 However, there was no further signal of change in the fish community in relation to GT1. The 319 relatively low intensity of GTs in these estuaries, the minimum score of EQR encountered in 320 this survey was a moderate status of estuarine quality in terms of macroalgal proliferation, 321 prevents dramatic changes in the fish communities at the global scale of estuaries. 


\subsection{Local-scale impacts of GT}

323 First, we analysed the effects of GTs directly at the trawling location using two indicators 324 (i.e., macroalgal mat surface ratio on beam trawl hauls, GT2, and Ulva spp. density per beam 325 trawl haul, GT4). From previous restricted small-scale analysis, these two indicators of the 326 local intensities of GTs were expected to have significant effects on the fish community. 327 However, none of the fish metrics presented a significant response to the GT descriptors at the 328 trawling locations. This lack of response was explained by the fish sampling protocol. Indeed, 329 during the WFD survey, trawl hauls were conducted beside the algal mats to avoid the 330 clogging of the net. Consequently, the surfaces and biomasses of algae were low at the 331 trawling locations. The maximum Ulva spp. density per beam trawl haul recorded was 0.05 $332 \mathrm{~kg} / \mathrm{m}^{2}$ in spring and $0.18 \mathrm{~kg} / \mathrm{m}^{2}$ in autumn. These low algal densities explain the absence of 333 significant effects on fish metrics. Indeed, Le Luherne et al. (2016) observed a minimum algal 334 density threshold of $0.30 \mathrm{~kg} / \mathrm{m}^{2}$ from which the fish community was significantly impacted by 335 expanded blade green macroalgae. The under-sampling of the algal mats during the surveys 336 explained the inability to provide a clear-cut assessment of the impacts of GTs on fish at the 337 trawling positions. To improve this assessment, the impacts of the GTs should be analysed 338 using a dedicated protocol that has been fitted for a before-after control-impact analysis (Le 339 Luherne et al., 2016).

340 To cope with the under-sampling of the algal mats during the fish surveys, we computed the 341 macroalgal mat surface ratio near the beam trawl hauls to test the effect of the spread of the 342 GTs beyond the algal mats. This local descriptor succeeded in detecting the effect of GTs on 343 estuarine fish.

344 A single significant and positive effect of GTs on resident fish was observed in spring based 345 on the GT index near the beam trawl hauls. This moderate effect may be caused by the very 
346 limited biomass and cover of algae before the proliferation season begins (Adams, 2005;

347 Andrades et al., 2014). Proliferation occurs between May and September (Merceron et al., 348 2007). As a result, a potential scale mismatch between the GT indicator and the fish surveys 349 may have occurred during the spring campaigns of certain years.

350 Conversely, half of the functional guilds presented a significant response to GT3 in autumn.

351 Resident and demersal fish responded positively to moderate algal cover in their vicinity 352 (Adams, 2005; Andrades et al., 2014). However, benthic and marine juvenile fish were 353 negatively impacted. This sensitivity of benthic and marine juvenile fish was already observed 354 during GTs, with a dramatic decrease in their density even during moderate proliferation (Pihl 355 et al., 2005; Le Luherne et al., 2016), as well as a decrease in individual performance (Le 356 Luherne et al., 2017).

\section{$357 \quad 4.4$ Generalization on the impact of GTs on fish}

358 The density of benthic fish responded negatively to the GT1 and GT3 indicators of 359 proliferation, with strong evidence supporting the sensitivity of this guild to GTs. This 360 sensitivity may be explained by the GT pattern of proliferation. GTs generate physical, 361 chemical and trophic perturbations that affect the fish community within a small area 362 (Nordström et al., 2007; Luherne et al., 2016). Physical stress is linked to the degradation of 363 the physical structure of the habitat. GTs first colonize the estuarine floor, modifying the 364 structure of the substratum (Solidoro et al., 1997), and then the water column is colonized (Le 365 Luherne et al., 2016). This modification of the bottom habitat by GTs mainly affects 366 macrobenthic communities (Quillien et al., 2015), including benthic fish (Le Luherne et al., 367 2016, 2017). Trophic perturbations are linked to a decrease in fish foraging efficiency within 368 the mats of Ulva spp (Nordström et al., 2007; Luherne et al., 2016). Finally, chemical 369 perturbations could occur with anoxic events within the sediment or at the sediment-water 
370 interface below the mats of Ulva spp. (Baden, 1990; Sundbäck et al., 1996). Therefore, the

371 benthic fish are the first to be impacted due to the degradation of their habitat (Wennhage,

372 2002; Wennhage and Pihl, 2007).

373 Following the rapid impact on benthic fish, shifts from a benthic to a pelagic community 374 could be observed after GT events (Bowen and Valiela, 2001). In the Baltic Sea, a massive 375 change in fish composition was associated with a decrease in the foraging efficiency of 376 predatory fish, and this change was induced by a GT (Pihl et al., 2005; Österblom et al., 377 2007). In fish survey data from the thirteen studied estuaries, the proportion of pelagic fish 378 was low $(<2 \%)$ with regard to previous estimations of European estuarine fish assemblages 379 (25\%; Elliott and Dewailly, 1995). This result revealed that the fish community was not fully 380 represented in the French WFD surveys. Indeed, the beam trawl is well adapted to sample the 381 benthic and demersal communities, but this method is inadequate for sampling pelagic fish 382 (Courrat et al., 2009; Delpech et al., 2010). GTs mainly disturb benthic and demersal species 383 (Le Luherne et al., 2016, and the present study); thus, the sampling bias did not compromise 384 the validity of the present approach for these fish guilds. Moreover, the effects of GTs on 385 pelagic fish occurred at a high level of GT proliferation, which was not observed in the 386 present data set in the sampled areas. However, potential shifts from a benthic to a pelagic 387 community after GT events (Bowen and Valiela, 2001) could not be assessed with this 388 sampling protocol. This type of assessment requires a dedicated protocol to investigate 389 massive algal mats and sample the whole fish community (Le Luherne et al., 2016).

390 Concerning the ecological guilds, in spite of the moderate level of GTs investigated, the 391 present approach provided evidence that GTs had negative consequences on marine juvenile 392 fish. The local productivity of several coastal and estuarine nursery-dependent marine fish 393 will be reduced with the proliferation of green macroalgae in coastal (Pihl et al., 2005, Brown 
394 et al., 2017) and estuarine areas (Peterson et al., 2000; Stoner et al., 2001). The juvenile stage 395 is a key life stage for fish population size (Stoner et al., 2001; Le Pape and Bonhommeau, 396 2015), and marine populations of species that are dependent on coastal and estuarine nursery 397 grounds and the related fisheries could be impacted by GTs, as observed in the Baltic Sea 398 (Baden, 1990; Jokinen et al., 2015). 


\section{Acknowledgements}

400 This work was supported by the French Fisheries Organization, France Filière Pêche and the 401 Loire-Bretagne Water Agency. We would like to thank all the scientific partners involved in 402 the estuarine fish surveys for the Water Framework Directive in Brittany (France), especially 403 Eric Thiebaut and Caroline Broudin (Université Pierre et Marie Curie, CNRS, Roscoff, 404 France), Elena Lucchetti (MNHN, Concarneau, France), Laurent Thieulle (Asconit, Lyon, 405 France), and Alexandre Carpentier (Université de Rennes 1, MNHN, Dinard, France). We 406 would also like to thank the three anonymous reviewers and the editor for their numerous 407 helpful suggestions, improvements and advice. 


\section{References}

Adams, S.M., 2005. Assessing cause and effect of multiple stressors on marine systems. Mar. Pollut. Bull. 51, pp. 649-657. https://doi.org/10.1016/j.marpolbul.2004.11.040

Aitchison, J., 1955. On the Distribution of a Positive Random Variable Having a Discrete Probability Mass at the Origin. J. Am. Stat. Assoc. 50, pp. 901. https://doi.org/10.2307/2281175

Aitchison, J., Brown, J.A.C., 1957. The lognormal distribution, Cambridge University Press.

Anderson, C.R., Moore, S.K., Tomlinson, M.C., Silke, J., Cusack, C.K., 2015. Living with Harmful Algal Blooms in a Changing World, in: Coastal and Marine Hazards, Risks, and Disasters. Elsevier, pp. 495-561.

Andrades, R., Gomes, M.P., Pereira-Filho, G.H., Souza-Filho, J.F., Albuquerque, C.Q., Martins, A.S., 2014. The influence of allochthonous macroalgae on the fish communities of tropical sandy beaches. Estuar. Coast. Shelf Sci. 144, pp. 75-81. https://doi.org/10.1016/j.ecss.2014.04.014

Baden, 1990. Eutrophication on Benthic Communities Including Fish: Swedish West Coast. AMBIO J. Hum. Environ. 19.

Beck, M., Airoldi, L., 2007. Loss, Status and Trends for Coastal Marine Habitats of Europe, in: Gibson, R., Atkinson, R., Gordon, J. (Eds.), Oceanography and Marine Biology. CRC Press, pp. 345-405.

Blaber, S.J.M., Blaber, T.G., 1980. Factors affecting the distribution of juvenile estuarine and inshore fish. J. Fish Biol. 17, pp. 143-162. https://doi.org/10.1111/j.10958649.1980.tb02749.x

Bowen, J.L., Valiela, I., 2001. The ecological effects of urbanization of coastal watersheds: historical increases in nitrogen loads and eutrophication of Waquoit Bay estuaries. Can. J. Fish. Aquat. Sci. 58, pp. 1489-1500. https://doi.org/10.1139/f01-094

Bray, J.R., Curtis, J.T., 1957. An ordination of the upland forest communities of Southern Wisconsin. Ecol. Monogr. 27, pp. 326-349. doi: 10.2307/1942268 
Bricker, S.B., Longstaff, B., Dennison, W., Jones, A., Boicourt, K., Wicks, C., Woerner, J., 2008. Effects of nutrient enrichment in the nation's estuaries: A decade of change. Harmful Algae 8, pp. 21-32. https://doi.org/10.1016/j.hal.2008.08.028

Brown, E.J., Vasconcelos, R.P., Wennhage, H., Bergström, U., Støttrup, J.G., van de Wolfshaar, K., Millisenda, G., Colloca, F., Le Pape O. (in press). Conflicts in the coastal zone: A rapid assessment of human impacts on commercially important fish species utilizing coastal habitat. Ices Journal of Marine Science. https://doi.org/10.1093/icesjms/fsx237

Courrat, A., Lobry, J., Nicolas, D., Laffargue, P., Amara, R., Lepage, M., Girardin, M., Le Pape, O., 2009. Anthropogenic disturbance on nursery function of estuarine areas for marine species. Estuar. Coast. Shelf Sci. 81, pp. 179-190. https://doi.org/10.1016/j.ecss.2008.10.017

Delpech, C., Courrat, A., Pasquaud, S., Lobry, J., Le Pape, O., Nicolas, D., Boët, P., Girardin, M., Lepage, M., 2010. Development of a fish-based index to assess the ecological quality of transitional waters: The case of French estuaries. Mar. Pollut. Bull. 60, pp. 908-918. https://doi.org/10.1016/j.marpolbul.2010.01.001

Diaz, R.J., Rosenberg, R., 2008. Spreading Dead Zones and Consequences for Marine Ecosystems. Science 321, pp. 926-929. https://doi.org/10.1126/science.1156401

Elliott, M., Dewailly, F., 1995. The structure and components of European estuarine fish assemblages. Neth. J. Aquat. Ecol. 29, pp. 397-417. https://doi.org/10.1007/BF02084239

Elliott, M., Quintino, V., 2007. The Estuarine Quality Paradox, Environmental Homeostasis and the difficulty of detecting anthropogenic stress in naturally stressed areas. Mar. Pollut. Bull. 54, pp. 640-645. https://doi.org/10.1016/j.marpolbul.2007.02.003

Fletcher, R.L., 1996. The Occurrence of "Green Tides" - a Review, in: Schramm, D.W., Nienhuis, P.D.P.H. (Eds.), Marine Benthic Vegetation, Ecological Studies. Springer Berlin Heidelberg, pp. 7-43.

Franco, A., Elliott, M., Franzoi, P., Torricelli, P., 2008. Life strategies of fishes in European estuaries: the functional guild approach. Mar. Ecol. Prog. Ser. 354, pp. 219-228. https://doi.org/10.3354/meps07203 
465

466

467

468

469

470

471

472

473

474

475

476

477

478

479

480

481

482

483

484

485

486

487

488

489

490

491

492

493

Gibson, R.N., 1994. Impact of habitat quality and quantity on the recruitment of juvenile flatfishes. Neth. J. Sea Res. 32, pp. 191-206. https://doi.org/10.1016/00777579(94)90040-X

Hastie, T., Tibshirani, R., 1999. Generalized additive models. Chapman \& Hall/CRC, Boca Raton, Fla.

Hodgkin, E.P., Birch, P.B., 1986. No simple solutions: Proposing radical management options for an eutrophic estuary. Mar. Pollut. Bull. 17, pp. 399-404. https://doi.org/10.1016/0025-326X(86)90317-6

Howell, P.T., Molnar, D.R., Harris, R.B., 1999. Juvenile winter flounder distribution by habitat type. Estuaries Coasts 22, pp. 1090-1095.

Hull, S.C., 1987. Macroalgal mats and species abundance: a field experiment. Estuar. Coast. Shelf Sci. 25, pp. 519-532. https://doi.org/10.1016/0272-7714(87)90112-0

Isaksson, I., Pihl, L., van Montfrans, J., 1994. Eutrophication-related changes in macrovegetation and foraging of young cod (Gadus morhua L.): a mesocosm experiment. J. Exp. Mar. Biol. Ecol. 177, pp. 203-217. https://doi.org/10.1016/00220981(94)90237-2

Jokinen, H., Wennhage, H., Lappalainen, A., Ådjers, K., Rask, M., Norkko, A., 2015. Decline of flounder (Platichthys flesus (L.)) at the margin of the species' distribution range. J. Sea Res. 105, pp. 1-9. https://doi.org/10.1016/j.seares.2015.08.001

Laurent, A.G., 1963. The Lognormal Distribution and the Translation Method: Description and Estimation Problems. J. Am. Stat. Assoc. 58, pp. 231-235. https://doi.org/10.1080/01621459.1963.10500844

Le Luherne, E., Le Pape, O., Murillo, L., Randon, M., Lebot, C., Réveillac, E., 2017. Influence of Green Tides in Coastal Nursery Grounds on the Habitat Selection and Individual Performance of Juvenile Fish. Plos one 12, https://doi.org/10.1371/journal.pone.0170110

Le Luherne, E., Réveillac, E., Ponsero, A., Sturbois, A., Ballu, S., Perdriau, M., Le Pape, O., 2016. Fish community responses to green tides in shallow estuarine and coastal areas. Estuar. Coast. Shelf Sci. 175, pp. 79-92. https://doi.org/10.1016/j.ecss.2016.03.031 
Le Pape, O., Bonhommeau, S., 2015. The food limitation hypothesis for juvenile marine fish. Fish Fish. 16, pp. 373-398. https://doi.org/10.1111/faf.12063

Le Pape, O., Chauvet, F., Mahévas, S., Lazure, P., Guérault, D., Désaunay, Y., 2003. Quantitative description of habitat suitability for the juvenile common sole (Solea solea, L.) in the Bay of Biscay (France) and the contribution of different habitats to the adult population. J. Sea Res. 50, pp. 139-149. https://doi.org/10.1016/S13851101(03)00059-5

Lehvo, A., Bäck, S., 2001. Survey of macroalgal mats in the Gulf of Finland, Baltic Sea. Aquat. Conserv. Mar. Freshw. Ecosyst. 11, pp. 11-18. https://doi.org/10.1002/aqc.428 Lepage, M., Harrison, T., Breine, J., Cabral, H., Coates, S., Galván, C., García, P., Jager, Z., Kelly, F., Mosch, E.C., Pasquaud, S., Scholle, J., Uriarte, A., Borja, A., 2016. An approach to intercalibrate ecological classification tools using fish in transitional water of the North East Atlantic. Ecol. Indic. 67, 318-327. https://doi.org/10.1016/j.ecolind.2016.02.055

Levin, S.A., 1992. The problem of pattern and scale in ecology. Ecology 73, pp. 1943-1967.

Liu, D., Keesing, J.K., He, P., Wang, Z., Shi, Y., Wang, Y., 2013. The world's largest macroalgal bloom in the Yellow Sea, China: Formation and implications. Estuar. Coast. Shelf Sci. 129, pp. 2-10. https://doi.org/10.1016/j.ecss.2013.05.021

Lyons, D.A., Arvanitidis, C., Blight, A.J., Chatzinikolaou, E., Guy-Haim, T., Kotta, J., OravKotta, H., Queirós, A.M., Rilov, G., Somerfield, P.J., Crowe, T.P., 2014. Macroalgal blooms alter community structure and primary productivity in marine ecosystems. Glob. Change Biol. 20, pp. 2712-2724. https://doi.org/10.1111/gcb.12644

Manel, S., Williams, H.C., Ormerod, S.J., 2002. Evaluating presence-absence models in ecology: the need to account for prevalence: Presence-absence modelling. J. Appl. Ecol. 38, pp. 921-931. https://doi.org/10.1046/j.1365-2664.2001.00647.x

Mason, N.W.H., Mouillot, D., Lee, W.G., Wilson, J.B., 2005. Functional richness, functional evenness and functional divergence: the primary components of functional diversity. Oikos 111, pp. 112-118. https://doi.org/10.1111/j.0030-1299.2005.13886.x 
Ménesguen, A., Piriou, J.-Y., 1995. Nitrogen loadings and macroalgal (Ulva sp.) Mass Accumulation in Brittany (France). Ophelia 42, pp. 227-237. https://doi.org/10.1080/00785326.1995.10431506

Merceron, M., Antoine, V., Auby, I., Morand, P., 2007. In situ growth potential of the subtidal part of green tide forming Ulva spp. stocks. Sci. Total Environ. 384, pp. $293-$ 305. https://doi.org/10.1016/j.scitotenv.2007.05.007

Nicolas, D., Lobry, J., Le Pape, O., Boët, P., 2010. Functional diversity in European estuaries: Relating the composition of fish assemblages to the abiotic environment. Estuar. Coast. Shelf Sci. 88, pp. 329-338. https://doi.org/10.1016/j.ecss.2010.04.010

Nixon, S.W., 1995. Coastal marine eutrophication: A definition, social causes, and future concerns. Ophelia 41, pp. 199-219. https://doi.org/10.1080/00785236.1995.10422044

Österblom, H., Hansson, S., Larsson, U., Hjerne, O., Wulff, F., Elmgren, R., Folke, C., 2007. Human-induced Trophic Cascades and Ecological Regime Shifts in the Baltic Sea. Ecosystems 10, pp. 877-889. https://doi.org/10.1007/s10021-007-9069-0

Pennington, M., 1983. Efficient Estimators of Abundance, for Fish and Plankton Surveys. Biometrics 39, pp. 281. https://doi.org/10.2307/2530830

Peterson, M.S., 2003. A Conceptual View of Environment-Habitat-Production Linkages in Tidal River Estuaries. Rev. Fish. Sci. 11, pp. 291-313. https://doi.org/10.1080/10641260390255844

Peterson, Summerson, Thomson, Lenihan, Grabowsk, Manning, Micheli, Johnson, 2000. Synthesis of linkages between benthic and fish communities as a key to protecting essential fish habitat. Bull. Mar. Sci. 66, pp. 759-774.

Pihl, L., Isaksson, I., Wennhage, H., Moksnes, P.-O., 1995. Recent increase of filamentous algae in shallow Swedish bays: Effects on the community structure of epibenthic fauna and fish. Netherland J. Aquat. Ecol. 29, pp. 349-358. https://doi.org/10.1007/BF02084234

Pihl, L., Modin, J., Wennhage, H., 2005. Relating plaice (Pleuronectes platessa) recruitment to deteriorating habitat quality: effects of macroalgal blooms in coastal nursery grounds. Can. J. Fish. Aquat. Sci. 62, pp. 1184-1193. https://doi.org/10.1139/f05-023 
Potter, I.C., Tweedley, J.R., Elliott, M., Whitfield, A.K., 2015. The ways in which fish use estuaries: a refinement and expansion of the guild approach. Fish Fish. 16, pp. 230239. https://doi.org/10.1111/faf.12050

555

Quillien, N., Nordström, M., Gauthier, O., Bonsdorff, E., Paulet, Y., Grall, J., 2015. Effects of macroalgal accumulations on the variability in zoobenthos of high-energy macrotidal sandy beaches. Mar. Ecol. Prog. Ser. 522, pp. 97-114. https://doi.org/10.3354/meps11151

R Development Core Team (2016). R: A language and environment for statistical computing. R Foundation for Statistical Computing, Vienna, Austria. URL http://www.Rproject.org/.

Raffaelli, D.G., Raven, J.A., Poole, L.J., 1998. Ecological impact of green macroalgal blooms. Oceanogr. Mar. Biol. Annu. Rev. 36, pp. 97-125.

Scanlan, C.M., Foden, J., Wells, E., Best, M.A., 2007. The monitoring of opportunistic macroalgal blooms for the water framework directive. Mar. Poll. Bull. 55, pp. 162171. https://doi.org/10.1016/j.marpolbul.2006.09.017.

Seitz, R.D., Wennhage, H., Bergstrom, U., Lipcius, R.N., Ysebaert, T., 2014. Ecological value of coastal habitats for commercially and ecologically important species. ICES J. Mar. Sci. 71, pp. 648-665. https://doi.org/10.1093/icesjms/fst152

Sfriso, A., Pavoni, B., 1994. Macroalgae and phytoplankton competition in the central Venice lagoon. Environ. Technol. 15, 1-14. https://doi.org/10.1080/09593339409385399

Smetacek, V., Zingone, A., 2013. Green and golden seaweed tides on the rise. Nature 504, pp. 84-88. http://dx.doi.org/10.1038/nature12860.

Solidoro C, Brando VE, Dejak C, Franco D, Pastres R, Pecenik G, 1997. Long term simulations of population dynamics of Ulva $r$. in the lagoon of Venice. Ecol Model.;102, pp. 259-72.

Spalding, M.D., Fox, H.E., Allen, G.R., Davidson, N., Ferdaña, Z.A., Finlayson, M., Halpern, B.S., Jorge, M.A., Lombana, A., Lourie, S.A., Martin, K.D., McManus, E., Molnar, J., Recchia, C.A., Robertson, J., 2007. Marine Ecoregions of the World: A 

https://doi.org/10.1641/B570707

582

Stefansson, G., 1996. Analysis of groundfish survey abundance data: combining the GLM and delta approaches. ICES J. Mar. Sci. 53, pp. 577-588. https://doi.org/10.1006/jmsc. 1996.0079

Stoner, A., Manderson, J., Pessutti, J., 2001. Spatially explicit analysis of estuarine habitat for juvenile winter flounder: combining generalized additive models and geographic information systems. Mar. Ecol. Prog. Ser. 213, pp. 253-271. https://doi.org/10.3354/meps213253

Sundbäck, K., Carlson, L., Nilsson, C., Jönsson, B., Wulff, A., Odmark, S., 1996. Response of benthic microbial mats to drifting green algal mats. Aquat. Microb. Ecol. 10, pp. 195-208. https://doi.org/10.3354/ame010195

Valiela, McClelland, Hauxwell, Behr, Hersh, Foreman, 1997. Macroalgal blooms in shallow estuaries: controls and ecophysiological and ecosystem consequences. Limnol. Oceanogr. 42, 1105-1118.

Vasconcelos, R.P., Le Pape, O., Costa, M.J., Cabral, H.N. (2013) Predicting estuarine use patterns of juvenile fish with Generalized Linear Models. Estuar, Coast. Shelf Sci. 120 ,pp. 64-74.

Villéger, S., Mason, N.W.H., Mouillot, D., 2008. New multidimensional functional diversity indices for a multifaceted framework in functional ecology. Ecology 89, pp. 22902301. https://doi.org/10.1890/07-1206.1

Wennhage, H., 2002. Vulnerability of newly settled plaice (Pleuronectes platessa L.) to predation: effects of habitat structure and predator functional response. J. Exp. Mar. Biol. Ecol. 269, pp. 129-145. https://doi.org/10.1016/S0022-0981(02)00005-9

Wennhage, H., Pihl, L., 2007. From flatfish to sticklebacks: assemblage structure of epibenthic fauna in relation to macroalgal blooms. Mar. Ecol. Prog. Ser. 335, pp. 187198. https://doi.org/10.3354/meps335187

Wheatley, M., Johnson, C., 2009. Factors limiting our understanding of ecological scale. Ecol. Complex. 6, pp. 150-159. https://doi.org/10.1016/j.ecocom.2008.10.011 
609 Wilkes, R., Best, M., Scanlan, C., Rossi, N., Kolbe, K., Salas Herrero, F., 2014.

610 Intercalibration of opportunistic macroalgae in coastal and transitional waters v4. UE 611 Water Framework Directive intercalibration technical report.22p.

612 Ye, N., Zhang, X., Mao, Y., Liang, C., Xu, D., Zou, J., Zhuang, Z., Wang, Q., 2011. “Green 613 tides" are overwhelming the coastline of our blue planet: taking the world's largest example. 614 Ecol. Res. 26, pp. 477-485. http://dx.doi.org/10.1007/s11284-011- 0821-8 


\section{$615 \quad$ Figure captions}

616 Figure 1: a) Locations (in WGS84 coordinates) of the studied estuaries in northwestern France 617 split into two ecoregions: north and south. The spatial protocol for the fish survey is provided 618 as an example for 2 of the thirteen estuaries studied, in (b) the Morlaix Estuary and (c) the 619 Aulne Estuary. Lines: the locations of beam trawls; hatched grid: mats of green macroalgae.

620

621 Figure 2: GLM prediction (with the 10-90\% confidence intervals) of the estuarine benthic fish 622 density (number/ha) according to the salinity and the two scores of the ecological quality ratio 623 (moderate in grey and high in black) in an estuary located in South Brittany that was sampled 624 in spring.

625

626 Figure 3: GLM prediction (with the 10-90\% confidence intervals) of the estuarine marine 627 juvenile density (number/ha) according to the percentage of the surface that had more than $62825 \%$ algal cover and was within $500 \mathrm{~m}$, in an estuary located in South Brittany that was 629 sampled in autumn. 

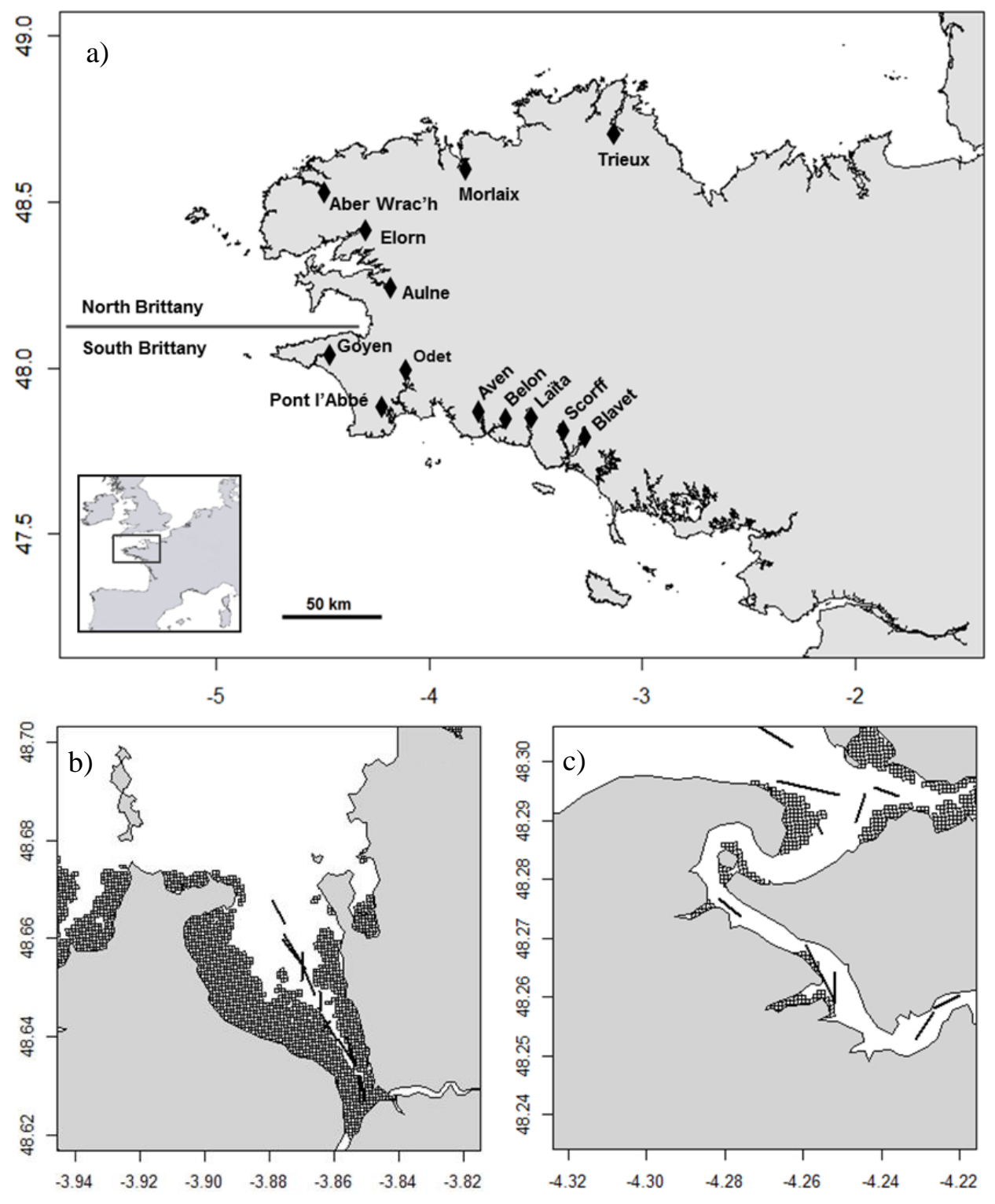

631 FIGURE 1

632

633 


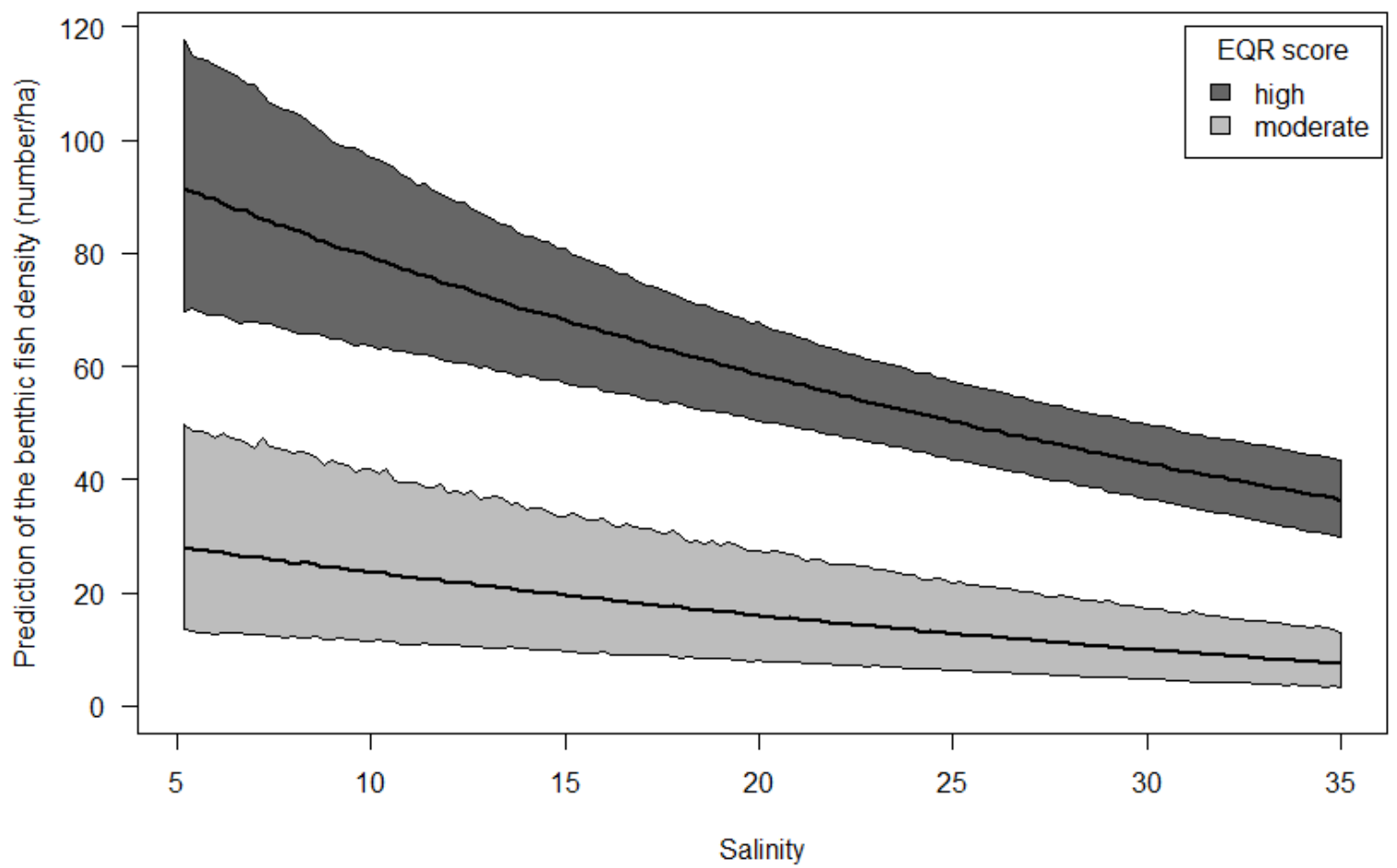

634

635 FIGURE 2

636 


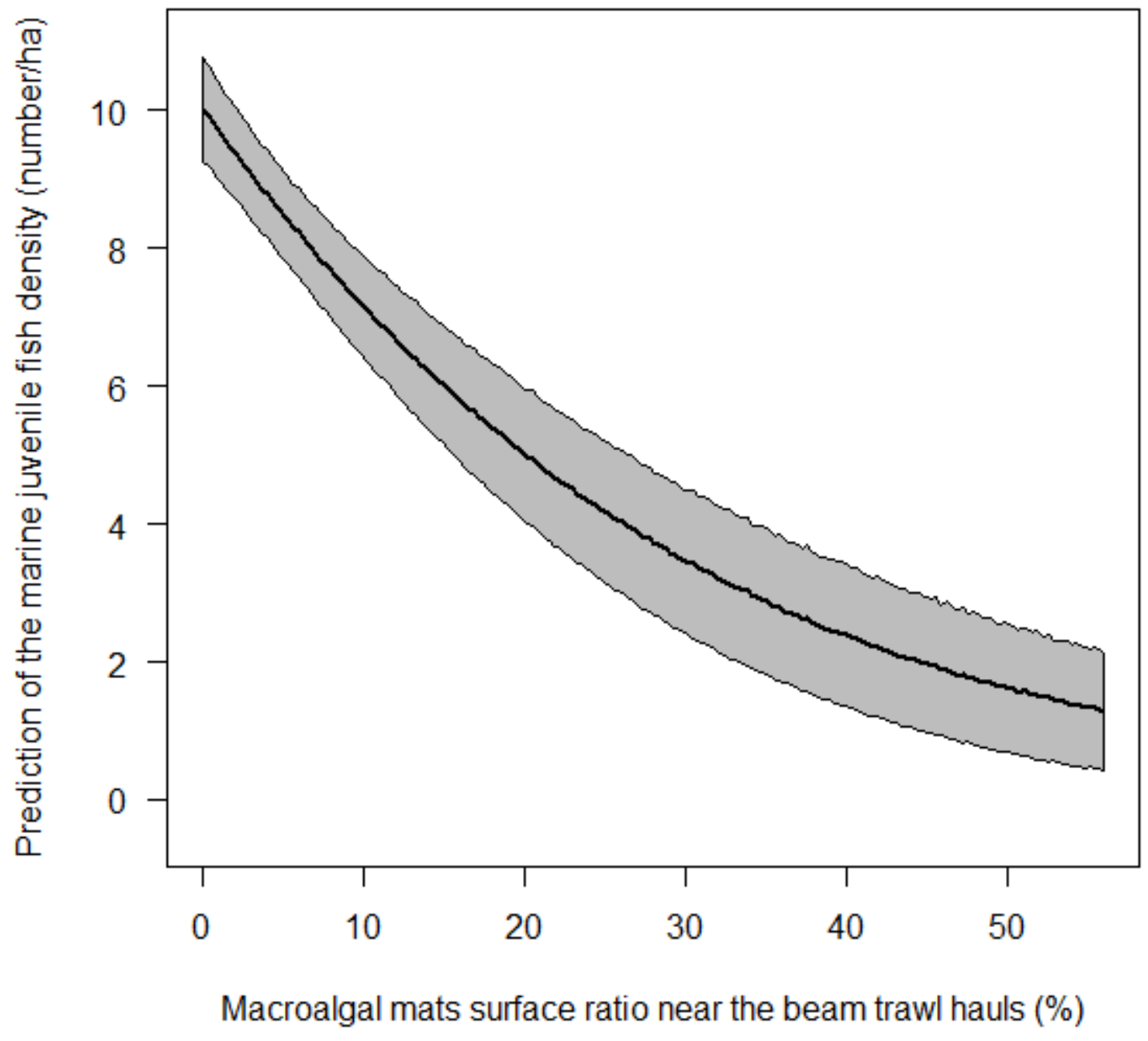

637

638 FIGURE 3 
640 Table 1: Total estuary area and intertidal area (ha) (Teichert et al, 2018), mean ecological 641 quality ratio (EQR) and the Estuarine and Lagoon Fish Index (ELFI, Delpech et al. 2010, 642 Lepage et al. 2016) and the associated scores for the thirteen studied estuaries.

\begin{tabular}{lcccccc}
\hline \multicolumn{1}{c}{ Estuary } & $\begin{array}{c}\text { Total area } \\
\text { (ha) }\end{array}$ & $\begin{array}{c}\text { Intertidal area } \\
\text { (ha) }\end{array}$ & $\begin{array}{c}\text { EQR } \\
(\text { mean })\end{array}$ & $\begin{array}{c}\text { EQR } \\
\text { score }\end{array}$ & $\begin{array}{c}\text { ELFI } \\
(\text { mean })\end{array}$ & $\begin{array}{c}\text { ELFI } \\
\text { (Score) }\end{array}$ \\
\hline Aber Wrach & 699 & 594 & 0.60 & Good & 0.46 & Moderate \\
Aulne & 1831 & 973 & 0.60 & Good & 0.59 & Moderate \\
Aven & 166 & 116 & 0.74 & Good & 0.88 & Good \\
Belon & 183 & 128 & 0.96 & High & 0.88 & High \\
Blavet-Scorff & 1531 & 863 & $0.47-0.8$ & & 0.67 & High \\
Elorn & 631 & 324 & 0.66 & Good & 0.96 & Good \\
Goyen & 155 & 111 & 0.93 & High & 0.65 & Moderate \\
Laita & 247 & 125 & 1.00 & High & 0.77 & Good \\
Morlaix river & 1361 & 1146 & 0.48 & Moderate & 0.44 & Good \\
Odet & 900 & 529 & 0.82 & High & 0.21 & Good \\
Pont l'Abbe & 646 & 545 & 0.43 & Moderate & 0.67 & High \\
Trieux & 777 & 478 & 0.55 & Moderate & 0.67 & Bad
\end{tabular}

643

644

645 Table 2: Definition of the three vertical distribution guilds and the two selected ecological 646 guilds (based on Franco et al., 2008; Potter et al., 2015).

\begin{tabular}{lll}
\hline Guild & Criterion & Definition \\
\hline Pelagic & $\begin{array}{l}\text { Vertical } \\
\text { distribution }\end{array}$ & Species living in the water column \\
Demersal & $\begin{array}{l}\text { Vertical } \\
\text { distribution }\end{array}$ & Species living in the water layer just above the bottom \\
Benthic & $\begin{array}{l}\text { Vertical } \\
\text { distribution }\end{array}$ & Species living on the substratum \\
Marine juvenile & Ecology & $\begin{array}{l}\text { Species using the shallow coastal waters and estuaries primarily as } \\
\text { nursery grounds }\end{array}$ \\
Resident & Ecology & $\begin{array}{l}\text { Species spending their whole life cycle in shallow coastal waters and } \\
\text { estuaries }\end{array}$ \\
\hline
\end{tabular}

647 
649 Table 3: Description of the four indicators of green tide proliferation.

\begin{tabular}{|c|c|c|c|c|}
\hline Indicator & Spatial scale & Variable & Green tide indicator & $\begin{array}{l}\text { Available } \\
\text { data }\end{array}$ \\
\hline GT1 & Large scale & Factor & Ecological quality ratio (EQR) & $2008-2014$ \\
\hline GT2 & Local scale & Continuous & $\begin{array}{l}\text { Macroalgal mat surface ratio on the } \\
\text { trawl haul (percentage) }\end{array}$ & $2008-2014$ \\
\hline GT3 & Local scale & Continuous & $\begin{array}{l}\text { Macroalgal mat surface ratio near } \\
\text { beam trawl hauls (percentage) }\end{array}$ & 2008-2014 \\
\hline GT4 & Local scale & Continuous & $\begin{array}{l}\text { Ulva spp. density per beam trawl } \\
\text { haul (kg.m-2 })\end{array}$ & 2013-2014 \\
\hline
\end{tabular}

650

651

652 
Table 4: Statistical significance of the generalized linear models of the fish metrics for the probability of presence, the positive densities and the species richness, and for the two GT indicators (large scales: GT1 and local scale: GT3). NS: nonsignificant; p-value: * $\leq 5 \%$, $* * \leq 1 \%$ and $* * * \leq 0.1 \%$

\begin{tabular}{|c|c|c|c|c|c|c|c|c|c|}
\hline \multirow[b]{2}{*}{ Fish metrics } & \multirow[b]{2}{*}{ Model } & \multicolumn{4}{|c|}{ Spring } & \multicolumn{4}{|c|}{ Autumn } \\
\hline & & Environmental drivers & $+\quad \begin{array}{c}\text { Large-scale } \\
\text { effect (GT1) }\end{array}$ & $\begin{array}{c}\text { Or } \\
+ \\
\end{array}$ & $\begin{array}{l}\text { Local-scale } \\
\text { effect (GT3) }\end{array}$ & Environmental drivers & $+\quad \begin{array}{c}\text { Large-scale } \\
\text { effect (GT1) }\end{array}$ & $\begin{array}{c}\text { Or } \\
+ \\
\end{array}$ & $\begin{array}{l}\text { Local-scale } \\
\text { effect (GT3) }\end{array}$ \\
\hline \multirow[t]{2}{*}{ Density } & Pres-abs & Depth $(* * *)+$ Ecoregion $(* * *)$ & $*$ & & NS & Depth $(* * *)$ & NS & & NS \\
\hline & $>0$ & Depth $(* * *)+$ Ecoregion $(* *)$ & $*$ & & NS & Depth $(* * *)$ & $* * *$ & & $*$ \\
\hline $\begin{array}{l}\text { Species } \\
\text { richness }\end{array}$ & & Depth $(* * *)+$ Ecoregion $(* *)$ & $* * *$ & & NS & $\begin{array}{l}\text { Ecoregion }(* * *)+\text { Depth } \\
(*)\end{array}$ & $* * *$ & & NS \\
\hline \multirow[t]{2}{*}{$\begin{array}{l}\text { Benthic guild } \\
\text { density }\end{array}$} & Pres-abs & $\begin{array}{l}\text { Ecoregion }(* * *)+\text { Salinity } \\
(* * *)\end{array}$ & $* * *$ & & NS & Ecoregion $(* * *)$ & $*$ & & NS \\
\hline & $>0$ & $\begin{array}{l}\text { Ecoregion }(* * *)+\text { Salinity } \\
(* * *)\end{array}$ & $* *$ & & NS & Ecoregion $(* * *)$ & $* * *$ & & $*$ \\
\hline \multirow[t]{2}{*}{$\begin{array}{l}\text { Demersal } \\
\text { guild density }\end{array}$} & Pres-abs & None & $* * *$ & & NS & Depth $(* * *)$ & NS & & NS \\
\hline & $>0$ & None & $* * *$ & & NS & Depth $(* * *)$ & $* * *$ & & $* * *$ \\
\hline $\begin{array}{l}\text { Pelagic guild } \\
\text { density }\end{array}$ & Pres-abs & $\begin{array}{l}\text { Class of salinity }(* * *)+\text { depth } \\
(* *)\end{array}$ & $* * *$ & & NS & None & $* * *$ & & NS \\
\hline \multirow{2}{*}{$\begin{array}{l}\text { Resident } \\
\text { guild density }\end{array}$} & Pres-abs & Depth $(* * *)$ & $* * *$ & & $*$ & Depth $(* * *)$ & $* *$ & & NS \\
\hline & $>0$ & Depth $(* * *)$ & $* * *$ & & NS & Depth $(* * *)$ & $* * *$ & & $* * *$ \\
\hline \multirow[t]{2}{*}{$\begin{array}{l}\text { MJ guild } \\
\text { density }\end{array}$} & Pres-abs & Salinity $(* * *)+$ Ecoregion $(* *)$ & $* * *$ & & NS & None & $* *$ & & $* * *$ \\
\hline & $>0$ & $\begin{array}{l}\text { Ecoregion }(* * *)+\text { Salinity } \\
(* * *)\end{array}$ & $* *$ & & NS & None & $* * *$ & & $* *$ \\
\hline
\end{tabular}




\section{Appendix}

660 Appendix 1

661

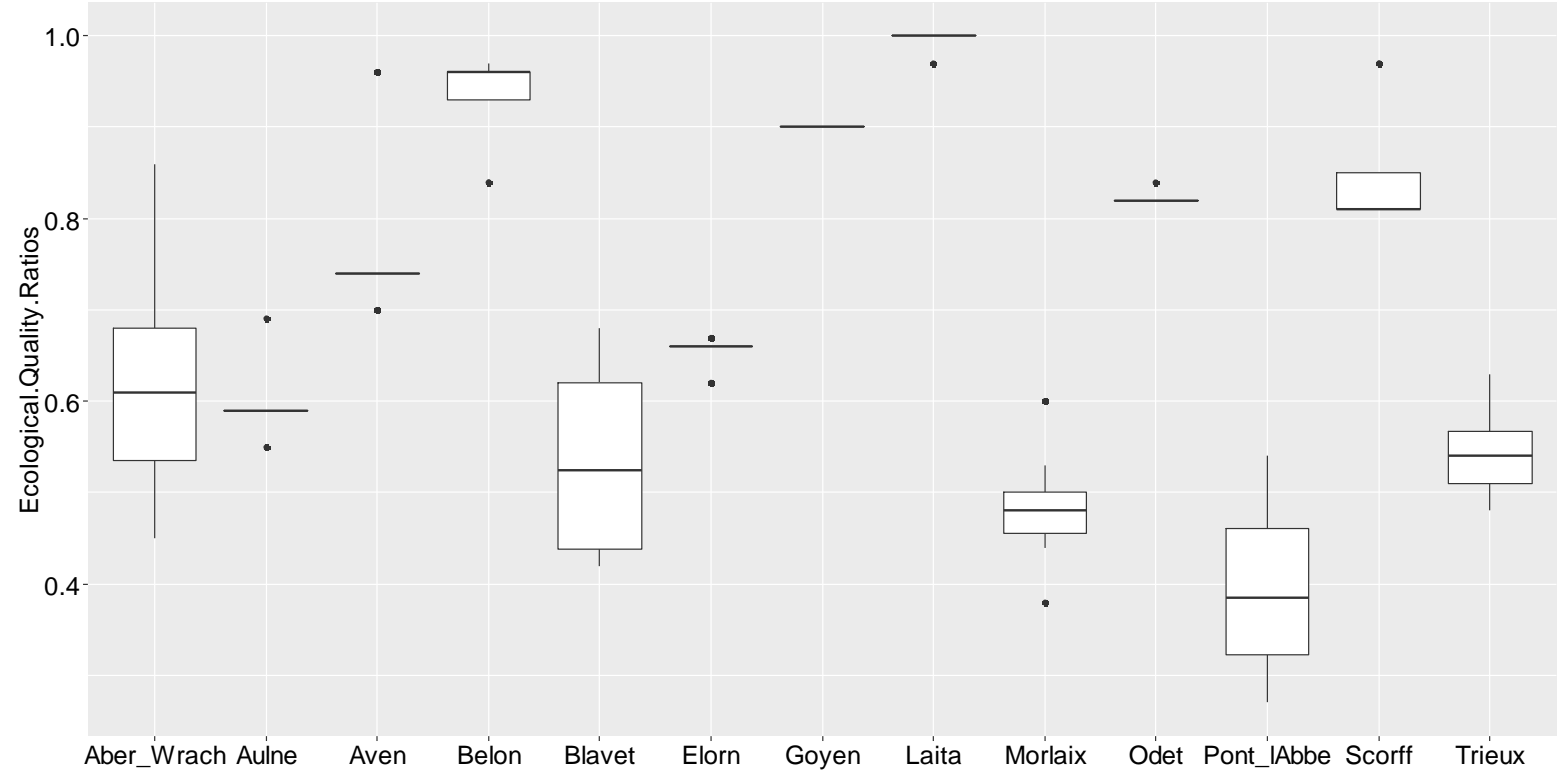

663 Supp. Fig. 1.1 Ecological quality ratios of the thirteen estuaries from 2008 to 2014 664 (boxplots: thick line: median; box: from the 0.25 quartile to the 0.75 quartile; whiskers: 6651.5 times the distance between the quartiles; circles: outlier values). 

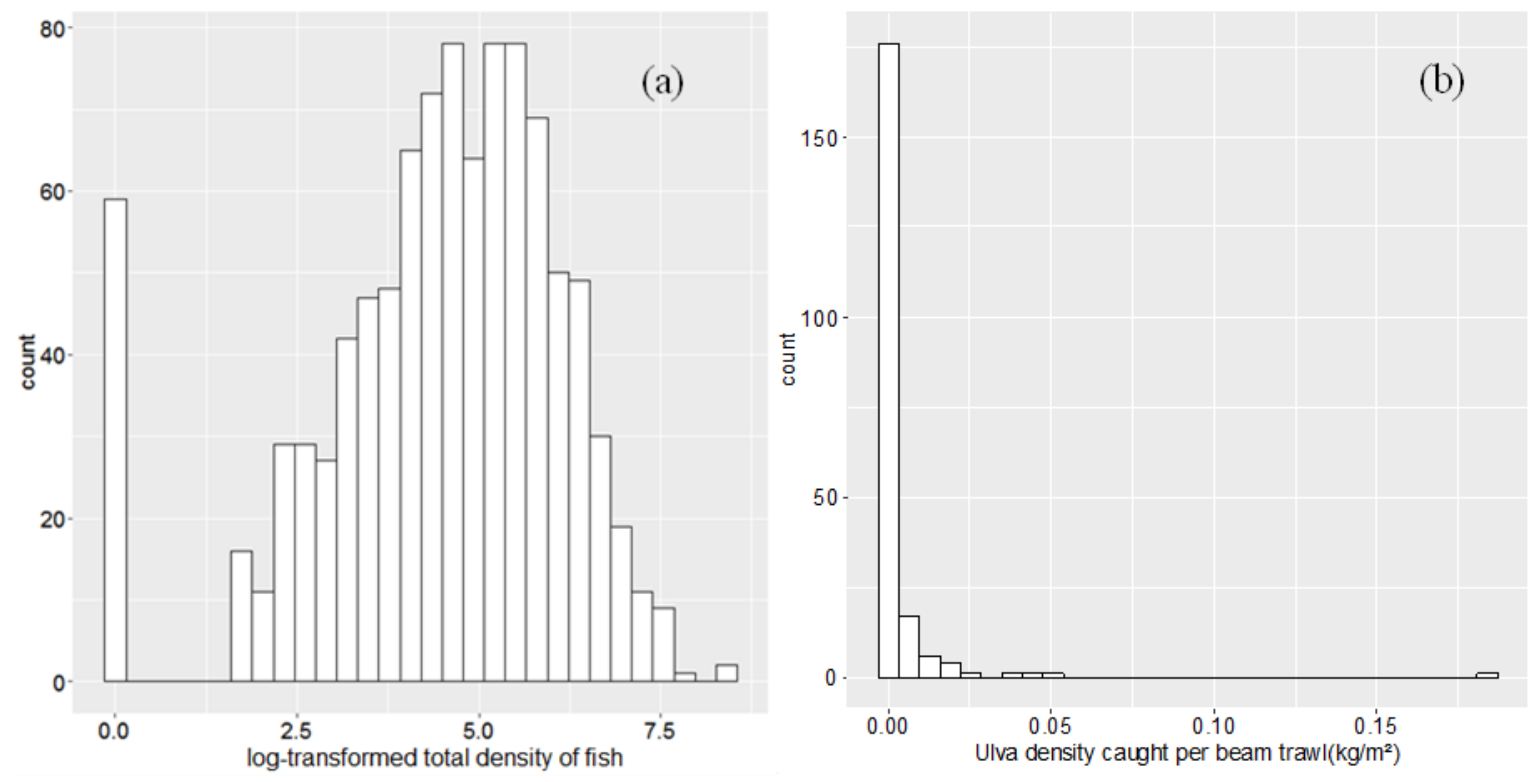

Supp. Fig. 1.2. (a) Spring distribution of the log-transformed total density of fish from the entire sampling of the thirteen estuaries; (b) distribution of Ulva spp. density $\left(\mathrm{kg} / \mathrm{m}^{2}\right)$ caught per beam trawl in 2013 and 2014. 


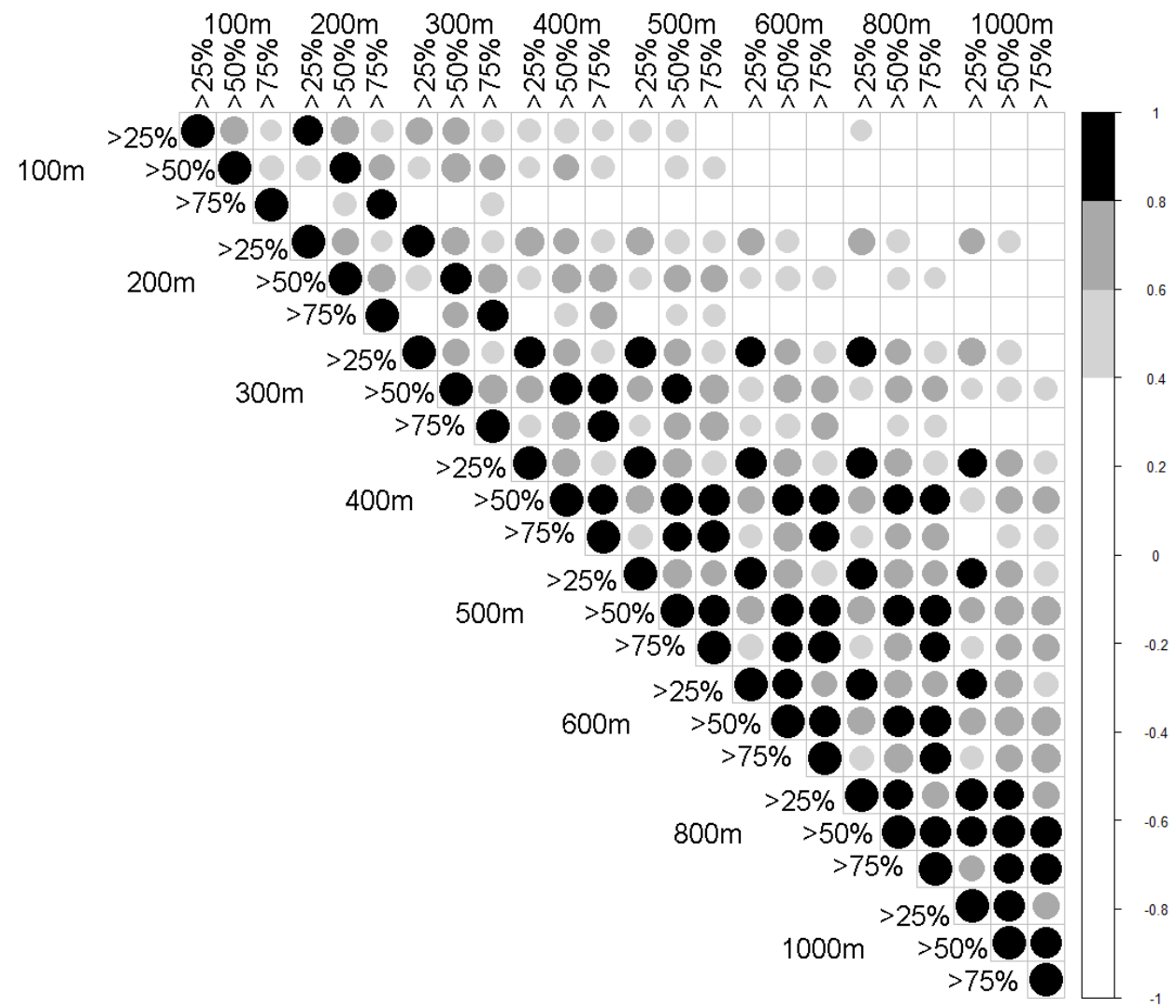

Supp. Fig. 2.2. Correlation matrix between the radius areas and the different algal density thresholds. The size and the color of circles represent the different levels of 676 correlation.

677

678

679 
a)
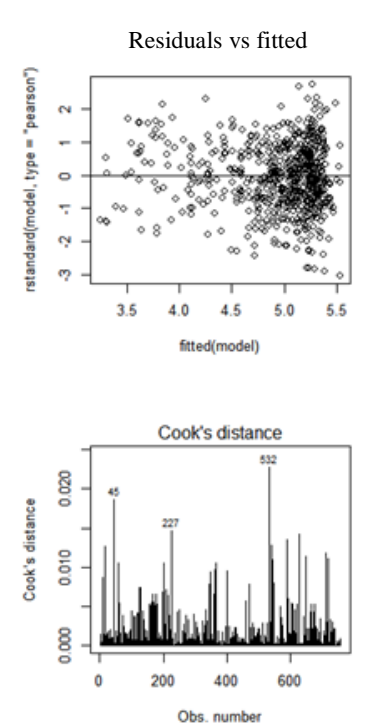

b)

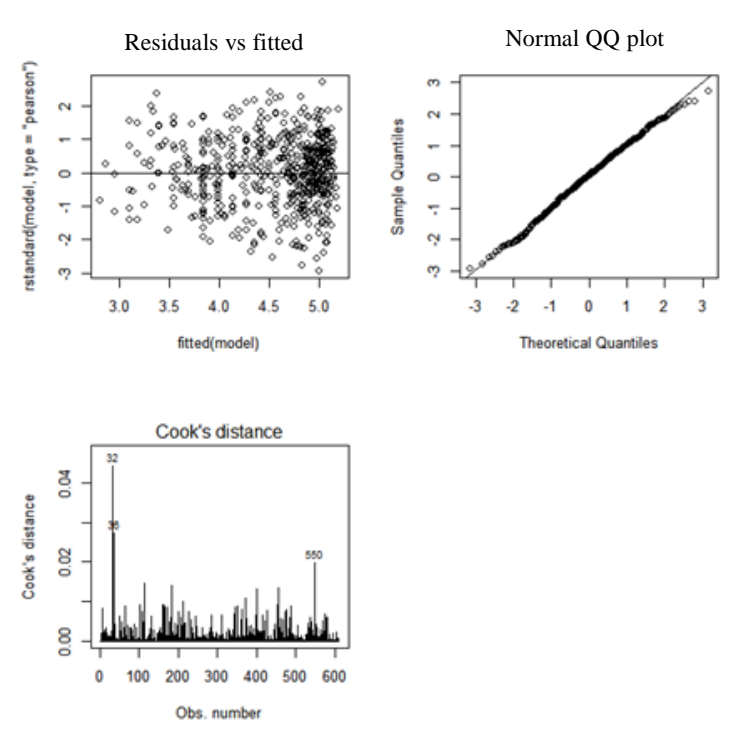

Supp. Fig. 3.1. Validation of the GLMs on the positive density for the total density of 681 fish (log scale) in: (a) autumn, (b) spring.

682 Supp. Table 3.1. Goodness-of-fit for the Binomial sub-models. AUC values and the p683 values associated.

\begin{tabular}{|lcccc|}
\hline & $\begin{array}{c}\text { Area under } \\
\text { curve }\end{array}$ & spring & \multicolumn{2}{c}{ autumn } \\
\hline Presence of fish & 0.79 & $* * *$ & Area under \\
curve & p value \\
Presence of the benthic guild & 0.84 & $* * *$ & 0.67 & $* * *$ \\
Presence of the demersal guild & NA & NA & 0.70 & $* * *$ \\
Presence of the pelagic guild & 0.67 & $* * *$ & 0.67 & $* * *$ \\
Presence of the resident guild & 0.61 & $* * *$ & NA & NA \\
Presence of the marine juvenile & 0.76 & $* * *$ & 0.62 & $* * *$ \\
\hline
\end{tabular}

684

685 